\title{
Dose of Biocoagulant-Mixing Rate Combinations for Optimum Reduction of COD in Wastewater
}

\author{
Maria Faustina Patricia ${ }^{1, *}$, Purwono $^{1}$, Mochamad Arief Budihardjo ${ }^{1}$ \\ ${ }^{1}$ Department of Environmental Engineering, Faculty of Engineering, Diponegoro University, Semarang - Indonesia
}

\begin{abstract}
Chemical oxygen demand (COD) in domestic wastewater can be treated using flocculationcoagulation process with addition of Oyster mushroom (Pleurotus ostreatus) in powder form as biocoagulant. The fungal cell wall of Oyster mushroom comprises of chitin that is high polyelectrolyte and can be function as an absorbent of heavy metals in wastewater. The effectiveness of flocculationcoagulation process in treating wastewater depends on dose of coagulant and mixing rate. Therefore, this study aims to determine the best combination of three variation of dose of biocoagulant which are 600 $\mathrm{mg} / 1,1000 \mathrm{mg} / \mathrm{l}$, and $2000 \mathrm{mg} / \mathrm{l}$ and mixing rate which are $100 \mathrm{rpm}, 125 \mathrm{rpm}$, and $150 \mathrm{rpm}$ that give the most reduction of COD in the wastewater. The result indicates that the combination of $1000 \mathrm{mg} / \mathrm{lof}$ biocoagulant and $100 \mathrm{rpm}$ of mixing rate were found to be the most optimum combination to treat COD in the wastewater with COD reduction of $47.7 \%$.
\end{abstract}

\section{Introduction}

Wastewater of canteen Dean of Faculty of Engineering Diponegoro University and canteen of Electrical Engineering Diponegoro University is one of the waste water that contributes to pollution if not processed first. Contaminant sources contained in waste water canteen of Dean of Faculty of Engineering Diponegoro University and canteen Electrical Engineering Diponegoro University, among others, is pathogenic bacteria and organic and inorganic solids. So that the result of pollution caused by canteen waste water make the channel become clogged, and odor and waste of processed product still not fulfill the required quality standard.

In domestic liquid waste canteen requires the main ingredients that can be used to wash the existing dishes of detergent or soap. Detergent is a derivate organic substance in which its accumulation will cause increased organic content in the waste water. Waste with organic content that continuously contaminates water bodies will cause negative impacts, such as foul odor, source of aquatic diseases, and water quality bodies that are not in accordance with its designation [1]. The detergent or soap used in the own washing industry can cause the resulting liquid waste to contain some contaminants which, if excessive, can be harmful to the environment is COD.

One of the treatment alternatives that can be done to degrade the pollutants is by using the coagulation and flocculation method in the jartest method.
Coagulation-flocculating water purification generally uses aluminum salt coagulant [2]. However, due to environmental reasons, many doubted the use of aluminum coagulant. Other alternatives such as iron salts and synthetic polymers actually began to popular, but the application is still tripping over the price factor and environmental problems that may arise. In recent years, interest in natural coagulants from plants has increased especially in the field of water and wastewater treatment in many developing countries [3].

Biocoagulant is said to have a bright future and attracts many researchers because of its abundance, low price, eco-friendly, multifunctional and biodegradable nature [4]. The use of extracts from plants has a function of coagulation and anti microbials that are safe for human health [5]. This research utilizes biocoagulant from an oyster mushroom (Pleurotusostreatus). White oyster mushroom is a type of oyster mushrooms that many farmers cultivated in Indonesia because of its adaptive to environmental changes and have high productivity [6]. And oyster mushrooms have environmentally friendly properties. The main constituent component of Basidiomycetes classroom cell wall is Kitin [7]. Chitin is known to possess properties such as bioactivity, biodegradability and has the properties to bind metallic ions such as Fe, $\mathrm{Cu}, \mathrm{Cd}, \mathrm{Hg}$, and has adsorption properties [8]. and has high polyelectrolyte properties that can act as adsorbents against heavy metals Wastewater [9].

Corresponding author: mariafaustinaps@gmail.com 


\section{Materials and Methods}

An oyster mushroom biocoagulant is first made by crushing oyster mushrooms by using a blender tool mixing $0.25 \mathrm{~kg}$ oyster mushrooms with $500 \mathrm{~L}$ of water. Once in the blender, then squeezed the mushroom in the napkin to remove the water. After that biocoagulant can be used.

The method used in this research is Jar test method. Jar test is a laboratory-scale experiment to determine optimum operating conditions for water and wastewater treatment processes. This method can determine the variation in the addition of coagulant dose and polymer, rotational speed, coagulant or polymer type variation, on a laboratory scale to predict actual water treatment requirements. The jar test method simulates the flocculation coagulation process to remove suspended solids and suspended organic matter [10]. Jar test is a procedure to study the effect of adding water coagulant; Used to determine the necessary dosage and operating conditions for effective coagulation and flocculation [11].

Table 1. Variation of mixing rate and bio coagulant dose

\begin{tabular}{|c|c|}
\hline $\begin{array}{c}\text { The dose of biocoagulant } \\
(\mathbf{m g} / \mathbf{l})\end{array}$ & Mixing rate (RPM) \\
\hline 600 & 100 \\
\hline 1000 & 125 \\
\hline 2000 & 150 \\
\hline
\end{tabular}

At the stage of implementation, first conducted preliminary test that is the initial characteristic of the domestic liquid waste both domestic canteens. The initial characteristics of the liquid wastes being examined are the values of COD and the $\mathrm{pH}$ of both wastewater. The value of COD from both domestic wastewater far exceeds the quality standard, so both require processing.

Table 2. Tools used in this research

\begin{tabular}{|l|l|l|}
\hline No & Tools & Information \\
\hline 1. & Measuring cup & $\begin{array}{l}\text { Waste water sample container } \\
\text { before screening }\end{array}$ \\
\hline 2. & $\begin{array}{l}\text { Desiccators } \\
\text { Chemistry }\end{array}$ & Coolant after heating \\
\hline 3. & Volumetric flask & $\begin{array}{l}\text { place of dilution samples to } \\
\text { be tested }\end{array}$ \\
\hline 4. & Test Tube & $\begin{array}{l}\text { To react liquid waste with } \\
\text { some reagent compounds }\end{array}$ \\
\hline 5. & COD reactor & $\begin{array}{l}\text { To analyze the oxygen } \\
\text { content in water }\end{array}$ \\
\hline 6. & Pipet & $\begin{array}{l}\text { To take the solution used for } \\
\text { the COD and Turbidity test }\end{array}$ \\
\hline 7. & Spektrofotometer & $\begin{array}{l}\text { Measures the results of COD } \\
\text { absorbance in wastewater } \\
\text { samples. }\end{array}$ \\
\hline 8. & Jartest & $\begin{array}{l}\text { As a tool for coagulation and } \\
\text { flocculation }\end{array}$ \\
\hline 9. & Stopwatch & To see the stirring time \\
\hline
\end{tabular}

Then after knowing the initial characteristics then done jar test stage by using some variation to the speed of jar test quick stirring and variation of dosage of oyster mushroom biocoagulant used. The selected variations are as show in Table 1.

Of all the variations obtained, this research was done duplo. In addition to the variations in the study, there are also fixed variables used in this study: jar test time is 12 minutes for rapid mixing rate stirring, 3 minutes for slow mixing rate stirring, and 1 hour for settling time. And for the slow mixing rate stirring speed used is 45 RPM . Tools and materials used in this research show in Table 2 and 3.

Table 3. Materials used in this research

\begin{tabular}{|c|l|}
\hline No & \multicolumn{1}{|c|}{ Materials } \\
\hline 1 & $\begin{array}{l}\text { Domestic liquid waste from Dean of Engineering } \\
\text { Faculty of Diponegoro University and Canton of } \\
\text { Electrical Engineering of Diponegoro University. }\end{array}$ \\
\hline 2 & Oyster Mushroom (Pleurotusostreatus) \\
\hline 3 & High Digestion \\
\hline 4 & $\mathrm{H}_{2} \mathrm{SO}_{4}$ \\
\hline 5 & Aquadest \\
\hline
\end{tabular}

\section{Results and Discussion}

In the preliminary test the initial characteristics of COD value of domestic waste received a value of $399.4 \mathrm{mg} / \mathrm{L}$ for the canteen Dean of the Faculty of Engineering Faculty of Diponegoro University and $636.9 \mathrm{mg} / \mathrm{L}$ for the Diponegoro University Electrical Engineering canteen. Where both COD values exceed the existing quality standard.

The results obtained from this research are as follows:

\section{A. Canteen of Dean of Faculty of Engineering Diponegoro University}

For fast mixing rate stirring speed 100 RPM, 125 RPM, 150 RPM, and control obtained COD value as show in Table 4.

Table 4. COD concentration of wastewater from Canteen of Dean, Faculty of Engineering, Diponegoro University.

\begin{tabular}{|c|c|c|}
\hline $\begin{array}{c}\text { Fast speed of } \\
\text { mixing rate }\end{array}$ & $\begin{array}{c}\text { Dose of } \\
\text { Biocoagulan } \\
(\mathbf{m g} / \mathbf{l})\end{array}$ & COD (mg/l) \\
\hline $100 \mathrm{RPM}$ & 600 & 272.26 \\
\hline & 1000 & 208.90 \\
\hline & 2000 & 248.28 \\
\hline & Control & 320.20 \\
\hline & 600 & 303.08 \\
\hline & 1000 & 226.02 \\
\hline & 2000 & 280.82 \\
\hline $150 \mathrm{RPM}$ & Control & 327.05 \\
\hline & 600 & 256.84 \\
\hline & 1000 & 217.46 \\
\hline & 2000 & 229.45 \\
\hline & Control & 323.63 \\
\hline
\end{tabular}


And get the total value of COD canteen of Dean of Faculty Engineering, Diponegoro University as Fig.1

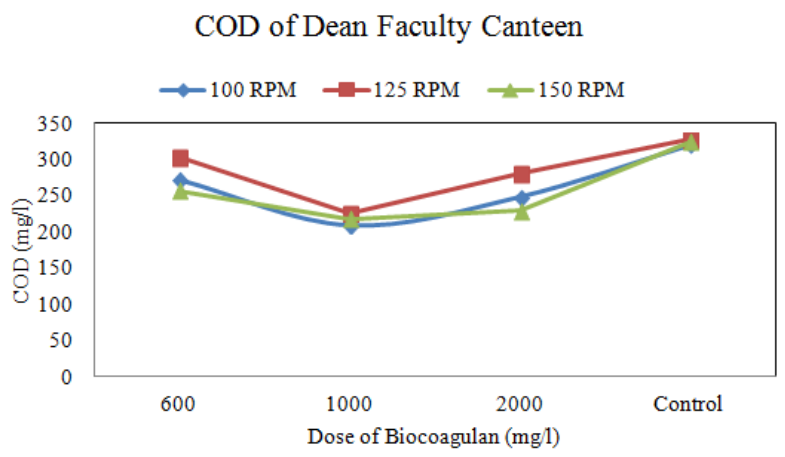

Fig.1 The COD concentration of wastewater from Canteen of Dean, Faculty of Engineering, Diponegoro University

\section{B. Canteen of Electrical Engineering, Diponegoro University}

The COD concentration of wastewater from the electrical canteen with mixing speed of 100 RPM, 125 RPM, 150 RPM, and control is shown in Table 5.

Table 5. COD concentration of wastewater from Canteen of Electrical Engineering, Faculty of Engineering, Diponegoro University (100 rpm)

\begin{tabular}{|c|c|c|}
\hline $\begin{array}{c}\text { Fast speed of } \\
\text { mixing rate }\end{array}$ & $\begin{array}{c}\text { Dose of } \\
\text { Biocoagulan } \\
(\mathrm{mg} / \mathrm{l})\end{array}$ & COD (mg/l) \\
\hline $100 \mathrm{RPM}$ & 600 & 385.27 \\
\hline & 1000 & 333.21 \\
\hline & 2000 & 436.64 \\
\hline $125 \mathrm{RPM}$ & 600 & 594.17 \\
\hline & 1000 & 452.05 \\
\hline & 2000 & 426.36 \\
\hline & Control & 464.04 \\
\hline $150 \mathrm{RPM}$ & 600 & 607.87 \\
\hline & 1000 & 424.65 \\
\hline & 2000 & 301.36 \\
\hline & Control & 457.19 \\
\hline
\end{tabular}

And get the total value of COD canteen of Electrical Engineering Diponegoro University as show in Fig. 2.

From the above results can be seen that the value of $\mathrm{COD}$ in the canteen Electrical Engineering is higher than the value of COD in the canteen Faculty of Engineering Diponegoro University due to the composition of domestic wastewater electro canteen more has more organic compounds such as vegetables. So the value of COD in the canteen Electrical
Engineering is higher than the value of COD in the Faculty Engineering Faculty canteen canteens.

COD of Electrical Engineering Canteen

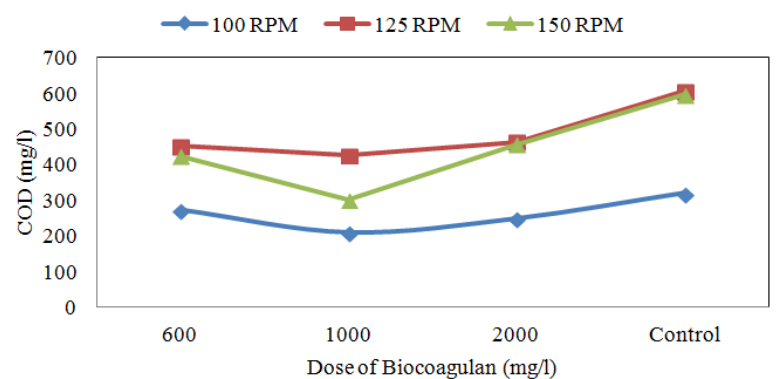

Fig.2 The COD concentration of wastewater from Canteen of electrical Engineering, Faculty of Engineering, Diponegoro University

And for the declining result of COD value on both domestic wastewater both have the efficiency of decreasing COD content equal to $47,7 \%$. And both of them can get the biggest decrease when using variation dose of fungus biokoagulan of $100 \mathrm{mg} / \mathrm{L}$ and with fast speed of stirring at jar test is 1000 RPM.

\section{Conclusions}

Oyster mushroom proven to decrease the levels of pollutants present in the liquid waste is COD. With coagulation and flocculation processing using oyster mushroom, it was proven to decrease COD content by $47.7 \%$ for domestic wastewater at variation for mixing rate at $1000 \mathrm{RPM}$ and $100 \mathrm{mg} / \mathrm{L}$ biocoagulant dose.

\section{References}

1. Adillah, K. W., Perencanaan Instalasi Pengolahan Air Limbah Rumah Sakit Pupuk Kaltim Prima Sangatta. Surabaya: Fakultas Sains dan Teknologi, Universitas Airlangga. (2012).

2. Bratby J.R.,Coagulation and Flocculation, With an Emphasis on Water and Wastewater Treatment, Uplands Press Ltd, Croydon.1980

3. Jahn S.A.A., Traditional Water Purification in Tropical Developing Countries: Existing Methods and Potential Application. Eschborn, GTZ, Germany. 1981

4. Madhavi, T. P., and R. Rajkumar. International Journal of ChemTech Research. Vol. 5 No.3, (2013)

5. Muyibi,S.A.\&Okuofu,C.A. International Journal of environmental studies,46,263-273 (1995)

6. Cahyana,Y.A., Muchrodji, M., Bakrun, Jamur Tiram: Pembibitan, Pembudidayaan, Analisis Usaha. Cetakan VI. Jakarta: Penebar Swadaya. (2001).

7. Griffin, D. H., Fungal Physiology. John Wiley and Sons, New York, (1981). 
8. Hirano, S., Chitin and Chitosan. In Ullman's Encyclopedia of Industrial Chemistry. Completely Revised Edition. Weinheim. New York, (1986)

9. Widyastuti, Khitin Ranjungan Sebagai Biokoagulan Dalam Penurunan Turbidity, BOD, COD, dan TSS Dalam Pengolahan Air LimbahFarmasi PT. Phapros, Tbk Semarang. Semarang: Diponegoro University., (2014)
10. Nugraheni, D. T. (2014). Cangkang Udang Sebagai Biokoagulan Untuk Penyisihan Turbidity, TSS, BOD dan COD pada Pengolahan Air Limbah Farmasi PT. Phapros Tbk. Semarang: Environment Engineering, Diponegoro University.

11. Crittenden,J.C., MWH's Water Treatment Principles and Design $3^{\text {rd }}$ Edition. New Jersey: John Wiley \& Sons, Inc, (2012). 